\title{
Preliminary Study: DNA Repair Gene Polymorphisms (RRM1, RRM2, ERCC2) In Left Ventricular Hypertrophy
}

\author{
Sol Ventrikül Hipertrofisinde (RRM1, RRM2, ERCC2) DNA Tamir Gen \\ Polimorfizmleri
}

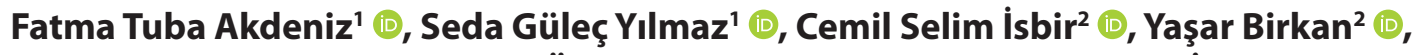

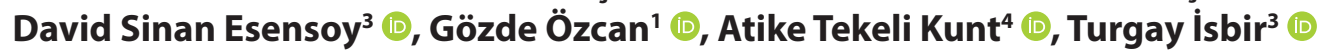 \\ 'Department of Molecular Medicine, Yeditepe University Institute of Health Sciences, İstanbul, Turkey \\ 2Department of Cardiovascular Surgery, Marmara University Pendik Training and Research Hospital, İstanbul, Turkey \\ ${ }^{3}$ Department of Medical Biology, Yeditepe University School of Medicine, Istanbul, Turkey \\ ${ }^{4}$ Department of Cardiovascular Surgery, Ankara Numune Training and Research Hospital, Ankara, Turkey
}

Cite this article as: Akdeniz FT, Güleç Yılmaz S, İsbir CS, Birkan Y, Esensoy DS, Özcan G, et al. Preliminary Study: DNA Repair Gene Polymorphisms (RRM1, RRM2, ERCC2) In Left Ventricular Hypertrophy. Experimed 2019; 9(3): 99-104.

\begin{abstract}
Objective: Left ventricular hypertrophy (LVH) accounts for one of the most important independent risk factors for cardiac diseases. In the present study, we investigate the relationship of DNA repair gene polymorphisms and LVH.

Material and Method: DNA samples isolated from peripheral blood were genotyped with real-time polymerase chain reaction (RT-PCR) for RRM1 (rs12806698), RRM2 (rs6859180) and ERCC2 (rs13181) genes.

Results: Although there were no significant differences for RRM2 $(p=0.365)$ and ERCC2 $(p=0.740)$ genes. RRM1 (A>C) CC genotype was significantly higher in the LVH than control groups $(p=0.018)$. RRM1gene wild type A allele carriers were significantly higher in the healthy controls than the LVH group $(p=0.029)$.

Conclusion: RRM1 gene CC genotype could be a risk factor, whereas the RRM1 gene AC genotype and the A allele might play a protective role against $L V H$.
\end{abstract}

Keywords: LVH, DNA repair genes, polymorphism

\section{INTRODUCTION}

During mammalian organogenesis heart is the first functionally formed organ. Each year approximately one million newborns are known to be born with heart defects, and one in every three people die because of heart diseases, thus cardiovascular diseases are becoming the leading cause of global mortality (1).

Left ventricular hypertrophy (LVH) is responsible for a compensatory mechanism to keep normal wall tension and to

\section{öz}

Amaç: Sol Ventrikül Hipertrofisi (SVH) kardiak hastalıklar için sık görülen bir risk faktörüdür. Bu çalışmada DNA tamir gen polimorfizimleri ve sol ventrikül hipertrofisi arasındaki ilişkiyi araştırdık.

Gereç ve Yöntem: Periferik kandan izole edilen DNA örnekleri RRM1 (rs12806698), RRM2 (rs6859180) ve ERCC2 (rs13181) genleri için Gerçek Zamanlı Polimeraz Zincir reaksiyon (GZ- PZR) ile genotiplendirildi.

Bulgular: Kontrol ve hasta grupları arasında RRM2 $(p=0,365)$ ve ERCC2 $(p=0,740)$ genleri için önemli fark olmamasına rağmen, RRM1 $(A>C) C C$ genotip frekansı SVH hastalarında kontrol grubuna göre anlamlı şekilde yüksek olarak bulundu $(p=0,018)$. RRM1 geni yabani tip A allel taşıyıcıları sağlıklı kontrolde SVH li hastalara göre anlamlı şekilde yüksek olarak tespit edildi $(p=0,029)$.

Sonuç: RRM1 CC genotipi SVH'ne karşı bir risk faktörü olabilirken RRM1 AC genotipi ve A alleli koruyucu role sahip olabilir.

Anahtar Kelimeler: SVH, DNA tamir genleri, polimorfizm

maintain cardiac output. When the left ventricle contracts, oxygenated blood is distributed to the body through the aortic valve. If hypertension exists making it difficult for blood to spread throughout the body, the left ventricle will strain to send the blood. This leads to an abnormal increase in the left ventricular (LV) mass, which is called LVH (2). LVH can occur because of hypertension, aortic valvular stenosis, aortic regurgitation, mitral regurgitation, and hypertrophic cardiomyopathy (3). Patients with LVH may experience car- 
diac failure, coronary artery disease, peripheral arterial disease and sudden death. Stroke risk is increased six-fold in LVH cases (4).

Ribonucleotide reductase (RR) is an enzyme catalyzing the conversion of Adenosine diphosphate (ADP) into Deoxyadenosine diphosphate (dADP) by removing the hydroxyl group from the second position of the ribose ring. Then, dADP is converted to Deoxyadenosine triphosphate (dATP) with the help of creatine kinase (5). The RR enzyme is required for the synthesis of deoxyribonucleotides, it is the rate-limiting step in DNA synthesis and it has two protein subunits important for its activity (6). Ribonucleotide reductase protein M1 (RRM1), is a catalytic activator, and ribonucleotide reductase protein M2 (RRM2), is a free radical-containing subunit $(7,8)$. Cardiac muscles prefer dATP as a more effective substrate than ATP for contraction, and with an increase in dATP levels, force generation, cross bridge cycling, and calcium sensitivity in the myocardium are known to be increased $(9,10)$. Excision Repair Cross-Complementing 2 (ERCC2) gene is a nucleotide excision repair mechanism (11).

There are only few studies examining the association between DNA repair genes and cardiovascular diseases. In this study, we aimed to investigate some DNA repair gene polymorphisms (RRM1, RRM2, ERCC2) and discuss their possible roles in the molecular mechanism of LVH.

\section{MATERIAL AND METHOD}

\section{Study participants}

All participants were selected from Marmara University Cardiovascular Surgery Department after detailed clinical examinations. All individuals signed an informed consent which was conducted in accordance with the ethical principles stated in the "Declaration of Helsinki". The study consisted of 15 patients with LVH and 24 healthy individuals. Echocardiographic parameters were measured using standard methods. Left ventricular systolic functions were estimated by measuring the Ejection Fraction (LVEF, \%).

\section{Genotyping}

Blood samples from all participants were collected in EDTA-tubes and DNA isolations were performed using Invitrogen iPrep Purification Instrument and Invitrogen iPrep Pure Linkg DNA Blood Kits (Invitrogen, Life Technologies, Carlsbad, CA, USA). DNA concentrations and optical density ratios were measured using NanoDrop 2000 (Thermoscientific, Waltham, MA, USA). Genotyping was performed using Applied Biosystems Fast Real-Time polymerase chain reaction (RT-PCR) instrument and TaqMan reagents primer-probe sets designed for RRM1 gene (rs12806698), RRM2 gene (rs6859180) and ERCC2 gene (rs13181) polymorphisms (Applied Biosystems, Foster City, CA, USA).

$L D L-H D L$ subfraction analysis: Serum samples were analyzed for LDL and HDL subfractions with the LIPOPRINT SYSTEM (Quantimetrix, CA, USA). This system is performed using high-resolution, polyacrylamide gel electrophoresis to separate lipo- protein particles into various fractions on the basis of size and density. LDL was analyzed with 7 subfractions including Large LDL (1 to 2) and Small LDL (3 to 7), while HDL was separated into 10 subfractions with Large HDL (1 to 3), Intermediate HDL (4 to 7 ) and Small HDL (8 to 10).

\section{Statistical Analysis}

Statistical analyses were performed using the Statistical Package for Social Sciences version 23 software (IBM Corp.; Armonk, NY, USA). Significant differences between groups were determined using the Student's t-test and demographic information was compared using Chi-square and Fisher's exact tests. Risk estimations were examined with Odds Ratio (OR) at 95\% Confidence Interval $(\mathrm{Cl}) . \mathrm{p}<0.05$ was denoted as statistically significant.

\section{RESULTS}

The demographic characteristics of the study population are given in Table 1. This study was conducted 39 samples; 4 female, 11 male in LVH group and 10 female 14 male in healthy control group. There were no statistically significant difference between healthy group and LVH group as demographic characterization $(p=0.359)$. The mean ages of the patients with LVH and the healthy control groups were $66.87 \pm 10.63$. and 62.46 $\pm 5.97(p=0.105)$. Systolic Blood Pressures (BP) were significantly higher in patients with LVH than the healthy control group $(p=0.017)$. However there were no significantly difference between the groups, LDL-HDL Subfractions values are given as demographic information and were not associated with polymorphism.

Echocardiographic parameters of LVH patients and healthy control group are given in Table 2. Genotype and allele frequencies between LVH patients and the healthy controls are listed in Table 3. Although there were significant differences for neither RRM2 $(A>G)$ gene $(p=0.365)$ nor ERCC2 $(G>T)$ $(p=0.740)$ genes, RRM1 ( $>C)$ gene was significantly different in the LVH and control groups ( $p=0.018)$. RRM1 heterozygote $A C$ genotype was significantly higher in the healthy control group ( $p=0.008)$, but homozygote mutant CC genotype was higher in the LVH group $(p=0.029)$. Regarding RRM1 $(A>C)$ polymorphism, in the patient group the percentage of wildtype $\mathrm{A}$ allele was $30 \%$ while mutant C allele was $70 \%$. RRM $1 \mathrm{~A}$ allele carriers were significantly higher in the healthy control group ( $p=0.029$ ), moreover RRM1 A allele carriers had a $\sim 4.5-$ fold decreased risk for $\mathrm{LVH}(\mathrm{OR}=0.22,95 \% \mathrm{Cl}=0.056-8.889)$. Our results indicated that RRM1gene CC genotype carrying might increase the risk of $\mathrm{LVH}$, whereas the RRM1 gene AC genotype may decrease the risk, and the $A$ allele might have a protective role against $\mathrm{LVH}$.

Although there was no statistically significant difference between the echocardiographic parameters and the RRM1 allele group, the echocardiographic parameters in the RRM1 A allele carrier group were lower than the non-A allele carrier group and the RRM1 $\mathrm{C}$ allele carrier group was higher than the non- $\mathrm{C}$ allele carier group (Table 4). 
Table 1. Demographic characteristics and clinical values for the patients with LVH and healthy control groups

\begin{tabular}{|c|c|c|c|c|c|}
\hline & \multirow{2}{*}{$\begin{array}{c}\text { LVH } \\
(n=15)\end{array}$} & \multirow{2}{*}{$\begin{array}{l}\text { Healthy Control } \\
\quad(n=24)\end{array}$} & \multirow[b]{2}{*}{$\mathbf{p}$} & \multicolumn{2}{|c|}{$\mathbf{9 5 \%}$ confidence interval (Cl) } \\
\hline & & & & Lower & Upper \\
\hline Sex (n) (Female/Male) & $4 / 11$ & $10 / 14$ & 0.359 & 0.551 & 0.794 \\
\hline Age (year) & $66.87 \pm 10.63$ & $62.46 \pm 5.97$ & 0.105 & -12.071 & 0.004 \\
\hline Height $(\mathrm{cm})$ & $165.67 \pm 8.46$ & $168.73 \pm 7.50$ & 0.199 & -7.775 & 1.658 \\
\hline Weight (kg) & $83.93 \pm 14.95$ & $81.23 \pm 12.80$ & 0.508 & -5.435 & 10.851 \\
\hline BMI $\left(\mathrm{kg} / \mathrm{m}^{2}\right)$ & $30.83 \pm 6.49$ & $28.67 \pm 5.23$ & 0.208 & -1.23880 & 5.55830 \\
\hline $\mathrm{BSA}\left(\mathrm{m}^{2}\right)$ & $1.91 \pm 0.17$ & $1.91 \pm 0.155$ & 0.997 & -0.09612 & 0.09646 \\
\hline Systolic BP (mmHg) & $137.33 \pm 19.35$ & $124.75 \pm 15.80$ & $0.017^{*}$ & 2.370 & 22.796 \\
\hline Diastolic BP(mmHg) & $83.67 \pm 6.11$ & $81.63 \pm 10.883$ & 0.497 & -3.940 & 8.024 \\
\hline Total Cholesterol (mg/dL) & $186.13 \pm 45.41$ & $186.90 \pm 42.14$ & 0.953 & -26.902 & 25.368 \\
\hline $\mathrm{TC}(\mathrm{mg} / \mathrm{dL})$ & $157.33 \pm 48.79$ & $157.93 \pm 103.0$ & 0.983 & -56.467 & 55.284 \\
\hline $\mathrm{LDL}(\mathrm{mg} / \mathrm{dL})$ & $118.27 \pm 40.32$ & $114.78 \pm 42.15$ & 0.783 & -21.819 & 28.802 \\
\hline $\mathrm{HDL}(\mathrm{mg} / \mathrm{dL})$ & $38.13 \pm 6.08$ & $42.20 \pm 12.23$ & 0.225 & -10.717 & 2.584 \\
\hline Large LDL (mg/dL) & $53.93 \pm 19.98$ & $53.66 \pm 15.00$ & 0.957 & -9.837 & 10.388 \\
\hline Small LDL (mg/dL) & $8.20 \pm 8.66$ & $4.11 \pm 6.11$ & 0.058 & -0.136 & 8.326 \\
\hline Large HDL (mg/dL) & $10.21 \pm 4.44$ & $12.44 \pm 4.371$ & 0.117 & -5.033 & 0.580 \\
\hline Intermediate HDL (mg/dL) & $22.93 \pm 6.28$ & $21.68 \pm 3.78$ & 0.399 & -1.708 & 4.212 \\
\hline Small HDL (mg/dL) & $6.43 \pm 3.13$ & $8.15 \pm .767$ & 0.139 & -4.019 & 0.582 \\
\hline VLDL (mg/dL) & $30.93 \pm 9.65$ & $30.95 \pm 20.086$ & 0.998 & -10.904 & 10.871 \\
\hline
\end{tabular}

Demografic and clinical laboratory data were expressed as mean \pm standard deviations (SD). LVH: left ventricular hypertrophy; $n$ : number of individuals; BMI: body mass index; BSA: body surface area; BP: blood pressure; TC: triglyceride; LDL: low density lipoprotein; HDL: high density lipoprotein; VLDL: very low density lipoprotein *statistically significant difference $(p<0.05)$.

Table 2. Echocardiographic parameters of patients with LVH and control groups

\begin{tabular}{|c|c|c|c|c|}
\hline & & $\begin{array}{c}\text { LVH } \\
(n=15)\end{array}$ & $\begin{array}{l}\text { Healthy Control } \\
\qquad(n=24)\end{array}$ & $\mathbf{p}$ \\
\hline Interventricular Septum Wall Thickness & $(\mathrm{mm})$ & $1.56 \pm 0.27$ & $0.95 \pm 0.11$ & $0.000^{*}$ \\
\hline LVH end diastolic diameter & $(\mathrm{mm})$ & $5.58 \pm 0.47$ & $4.09 \pm 0.23$ & $0.000^{*}$ \\
\hline LVH Mass & (g) & $583.48 \pm 132.13$ & $218.85 \pm 33.00$ & $0.000 *$ \\
\hline LVH Mass Index & $\left(\mathrm{g} / \mathrm{m}^{2}\right)$ & $310.98 \pm 71.67$ & $118.51 \pm 23.41$ & $0.000^{*}$ \\
\hline
\end{tabular}

\section{DISCUSSION}

Despite advances in ventricular dysfunction epidemiology, the mechanism of genotypic and phenotypic variations remains unclear. In this study, the relationship of RRM1 (rs12806698), RRM2 (rs6859180) and ERCC2 (rs13181) polymorphisms on LVH were investigated. The AC genotype of RRM1 gene was higher in the control group, indicating that the $\mathrm{AC}$ genotype decreases the risk of LVH; The CC genotype was in a high proportion in LVH patients, so carrying the A allele could lower the risk for LVH as its frequency was higher in the healthy control group than in the LVH patients. 
Table 3. Genotype and allele frequencies between patients with LVH and the healthy controls

\begin{tabular}{|c|c|c|c|c|c|c|}
\hline \multirow[b]{2}{*}{ Polymorphism } & \multirow{2}{*}{$\begin{array}{l}\text { LVH } \\
\text { n (\%) }\end{array}$} & \multirow{2}{*}{$\begin{array}{l}\text { Healthy Control } \\
\text { n (\%) }\end{array}$} & \multirow[b]{2}{*}{$\mathbf{p}$} & \multirow[b]{2}{*}{ Odds ratio (OR) } & \multicolumn{2}{|c|}{$\mathbf{9 5 \%}$ confidence interval (Cl) } \\
\hline & & & & & Lower & Upper \\
\hline RRM1 (rs13181) & $n=15$ & $n=24$ & $0.018^{*}$ & & & \\
\hline AA & $3(20.0)$ & $2(8.3)$ & 0.354 & 2.750 & 0.402 & 18.804 \\
\hline AC & $3(20.0)$ & $16(66.7)$ & $0.008^{*}$ & 0.125 & 0.027 & 0.573 \\
\hline \multirow[t]{2}{*}{ CC } & $9(60.0)$ & $6(25)$ & $0.029^{*}$ & 4.500 & 1.125 & 17.993 \\
\hline & Allelic count & Allelic count & & & & \\
\hline A & $9(30)$ & $20(41.6)$ & $0.029^{*}$ & 0.222 & 0.056 & 0.889 \\
\hline C & $21(70)$ & $28(58.4)$ & 0.354 & 0.364 & 0.053 & 2.487 \\
\hline RRM2 (rs13181) & $n=15$ & $n=16$ & 0.365 & & & \\
\hline AA & $12(80.0)$ & $11(68.8)$ & 0.685 & 1.818 & 0.350 & 9.455 \\
\hline AG & $3(20.0)$ & $3(18.7)$ & 0.930 & 1.083 & 0.182 & 6.439 \\
\hline \multirow[t]{2}{*}{ GG } & $0(0)$ & $2(12.5)$ & 0.484 & 0.875 & 0.727 & 1.053 \\
\hline & Allelic count & Allelic count & & & & \\
\hline A & $18(85.7)$ & $25(78.1)$ & 0.484 & 0.194 & 0.054 & 0.691 \\
\hline G & $3(14.3)$ & $7(21.9)$ & 0.685 & 0.848 & 0.188 & 3.823 \\
\hline ERCC2 (rs13181) & $n=15$ & $n=24$ & 0.740 & & & \\
\hline GG & $4(26.7)$ & $5(20.8)$ & 0.711 & 1.382 & 0.305 & 6.255 \\
\hline GT & $5(33.3)$ & $11(45.8)$ & 0.440 & 0.591 & 0.155 & 2.258 \\
\hline \multirow[t]{2}{*}{ TT } & $6(40)$ & $8(33.3)$ & 0.673 & 1.333 & 0.350 & 5.076 \\
\hline & Allelic count & Allelic count & & & & \\
\hline G & $13(43.3)$ & $21(43.75)$ & 0.673 & 0.750 & 0.197 & 2.855 \\
\hline $\mathrm{T}$ & $17(56.7)$ & 27 (56.25) & 0.711 & 0.724 & 0.160 & 3.276 \\
\hline
\end{tabular}

Table 4. The relationship between the echocardiographic parameters of patients with LVH according to RRM1 allele carriers

\begin{tabular}{llccccc}
\hline & & $\begin{array}{c}\text { RRM1 A allele } \\
\text { carriers } \mathbf{n = 6}\end{array}$ & $\begin{array}{c}\text { RRM1 non-A } \\
\text { allele carrier } \mathbf{n = 9}\end{array}$ & $\begin{array}{c}\text { RRM1 C allele } \\
\text { carriers } \mathbf{n = 1 2}\end{array}$ & $\begin{array}{c}\text { RRM1 non-C } \\
\text { allele carrier } \mathbf{n = 3}\end{array}$ \\
\hline Interventricular Septum Wall Thickness & $(\mathrm{mm})$ & $1.53 \pm 0.35$ & $1.64 \pm 0.12$ & $1.65 \pm 0.13$ & $1.36 \pm 0.45$ \\
\hline LVH end diastolic diameter & $(\mathrm{mm})$ & $5.23 \pm 0.41$ & $5.46 \pm 0.25$ & $5.43 \pm 0.25$ & $5.13 \pm 0.56$ \\
\hline LVH Mass & $(\mathrm{g})$ & $577.51 \pm 87.35$ & $629.81 \pm 85.84$ & $629.15 \pm 75.94$ & $526.13 \pm 94.43$ \\
\hline LVH Mass Index & $\left(\mathrm{g} / \mathrm{m}^{2}\right)$ & $262.64 \pm 122.67$ & $335.43 \pm 55.49$ & $333.52 \pm 48.99$ & $285.01 \pm 52.12$ \\
\hline Data were expressed as mean \pm SD. LVH: left ventricular hypertrophy; $\mathrm{n}$ : number of individuals & &
\end{tabular}

The clinical and laboratory studies showed that dATP acts as a substrate for de-membranated cardiac muscle contraction and is a more effective substrate than ATP. It increases left ventricular contractions both in normal and infarcted heart regions.
dATP can be synthesized through a reductive reaction catalyzed by the RRM1 enzyme. Furthermore it has been asserted that RR inhibition could be a therapeutic target of atheroproliferative disorders (12). 
Unrepaired DNA base damage triggers apoptotic pathways (13) and apoptosis accelerates myocyte loss and causes myocardial dysfunctions (14). Apoptosis-induced myocyte damage causes abnormal loading and increased wall stress which results in heart failure. In spite of compensatory mechanisms, insufficient DNA repair could lead to myocyte apoptosis that begins at the onset of hypertrophy (14).

The RRM1 gene, is a molecular target of gemcitabine, and has very important roles. Increased RRM1 expression levels were correlated with longer survival rates, while it is a disadvantage to have high levels of RRM1 expression because of a decreased efficacy of chemotherapy. Two single nucleotide polymorphisms were discovered upstream of the first exon of the RRM 1 gene. They are an adenine/cytosine change at (-) 37 nucleotide position and a cytosine/thymidine change at (-) 524 nucleotide position. These polymorphisms affect promoter activity highly associated with overall survival (15).

Ribonucleotide reductase activity has a role not only in cell cycle but also in the proper functioning of myocytes. RR overexpression increases dATP, affecting the contractility of cardiomyocytes. Elevated cardiomyocyte dATP levels via RR protein increases muscle contractility, subsequently basal cardiac function increases by actin-myosin binding and cycling. Thus, even in cardiac overload, myocytes could maintain normal myocardial energetics (9). Furthermore, it has been claimed that cardiac-specific RR gene therapy may reverse cardiac dysfunction. In the animal model, heart failure treated with the RR gene was inducing myosin activation (10).

According to analysis of sex differences, genders may account for the risk of cardiovascular diseases. In terms of cardiac adaptation, the left ventricular dimensions are smaller and left ventricular performance is higher in women compared to men. Sex differences can play a role in LVH however, in this study, there was no statistical significance related to gender and LVH (16).

One of the most important factors in the pathogenesis of LVH is systolic BP. It has been shown that there is a direct relationship between the incidence of LVH and the level of the systolic BP. Our study supports this finding due to the fact that the difference in the systolic BP between the groups is statistically significant and the mean is higher in patients with LVH than the healthy control group (17).

\section{CONCLUSION}

DNA repair mechanisms have important roles in the molecular mechanisms of LVH. Our results showed that there was a relationship between RRM1 gene polymorphism and LVH risk. To clarify and confirm this association, further studies on larger populations are required. If future studies continue to support the current findings, RRM1 gene could be considered as a therapeutic decision target.
Ethics Committee Approval: Ethics committee approval was received for this study from the Ethics Committee of Marmara University School of Medicine.

Informed Consent: Written informed consent was obtained from the patients who participated in this study.

Peer-review: Externally peer-reviewed.

Author Contributions: Concept - T.I., I.Y.; Supervision - T.I., I.Y; Materials - H.E., H.S.; Data Collection and/or Processing - B.T.H.,M.T.H., C.H.; Analysis and/or Interpretation - C.H., I.Y., A.E., Ü.Z.; Literature Search - B.T.H., D.S. M.T.H..; Writing - B.T.H., C.H.; Critical Reviews - H.S., I.Y., B.T.H.

Conflict of Interest: The authors have no conflict of interest to declare.

Financial Disclosure: The authors declared that this study has received no financial support.

Etik Komite Onayı: Bu çalışma için etik komite onayı Marmara Üniversite Tıp Fakültesi'nden alınmıştır.

Hasta Onamı: Yazılı hasta onamı bu çalışmaya katılan hastalardan alınmıştır.

Hakem Değerlendirmesi: Dış bağımsız.

Yazar Katkıları: Fikir - T.I., I.Y.; Denetleme - T.I., I.Y.; Gereçler - H.E., H.S.; Veri Toplanması ve/veya Işslemesi - B.T.H., M.T.H., C.H.; Analiz ve/veya Yorum - C.H., I.Y., A.E., Ü.Z.; Literatür Taraması - B.T.H., D.S. M.T.H.; Yazan - B.T.H., C.H.; Eleştirel İnceleme - H.S., I.Y., B.T.H.

Çıkar Çatışması: Yazarlar çıkar çatışması bildirmemişlerdir.

Finansal Destek: Yazarlar bu çalışma için finansal destek almadıklarını beyan etmişlerdir.

\section{REFERENCES}

1. Benjamin EJ, Blaha MJ, Chiuve SE, Cushman M, Das SR, Deo R, et al. American Heart Association Statistics Committee and Stroke Statistics Subcommittee. Heart Disease and Stroke Statistics-2017 Update: A Report From the American Heart Association. Circulation 2017; 135: 146-603. [CrossRef]

2. Messerli FH, Schmieder R. Left ventricular hypertrophy. A cardiovascular risk factor in essential hypertension. Drugs 1986; 31: 192201. [CrossRef]

3. Davidson, BP, Giraud GD. Left ventricular function and the systemic arterial vasculature: remembering what we have learned. J Am Soc Echocardiogr 2012; 25: 891-94. [CrossRef]

4. Pokharel P, Bella JN. Regression of left ventricular hypertrophy: Lessons from clinical trials. OA Evidence-Based Medicine 2013; 1: 13. https://doi.org/10.13172/2053-2636-1-2-1110. [CrossRef]

5. Elledge SJ, Zhou Z, Allen JB. Ribonucleotide reductase: regulation, regulation, regulation. Trends Biochem Sci 1992; 17: 11923. [CrossRef]

6. Oh IJ, Ban HJ, Kim KS, Song SY, Na KJ, Kim YH, et al. Response to gemcitabine-platinum chemotherapy by single nucleotide polymorphisms of RRM1 and ERCC1 genes in patients with non-smallcell lung cancer. Thorac Cancer 2012; 3: 19-26. [CrossRef]

7. Thomson KS, Odom GL, Murry CE, Mahairas GG, Moussavi-Harami F, Teichman SL, et al. Translation of Cardiac Myosin Activation with 
2-deoxy-ATP to Treat Heart Failure via an Experimental Ribonucleotide Reductase-Based Gene Therapy. JACC Basic TransI Sci 2016; 1: 666-79. [CrossRef]

8. Korte FS, Dai J, Buckley K, Feest ER, AdamekN, Geeves MA, et al. Upregulation of cardiomyocyte ribonucleotide reductase increases intracellular 2 deoxy-ATP, contractility, and relaxation. J Mol Cell Cardiol 2011; 51: 894-901. [CrossRef]

9. Nowakowski SG, Kolwicz SC, Korte FS, Luo Z, Robinson-Hamm JN, Page JL, et al. Transgenic overexpression of ribonucleotide reductase improves cardiac performance. Proc Natl Acad Sci U S A 2013; 110: 6187-92. [CrossRef]

10. Kadota S, Carey J, Reinecke H, Leggett J, Teichman S, Laflamme $M A$, et al. Ribonucleotide reductase-mediated increase in dATP improves cardiac performance via myosin activation in a large animal model of heart failure. Eur J Heart Fail 2015; 17: 772-81. [CrossRef]

11. Cervelli T, Borghini A, Galli A, Andreassi MG. DNA damage and repair in atherosclerosis: current insights and future perspectives. Int J Mol Sci 2012; 13:16929-44. [CrossRef]

12. Gallaugher LD, Henry JC, Kearns PN, Elford HL, Bergdall VK, Cardaunel AJ. Ribonucleotide reductase inhibitors reduce ath- erosclerosis in a double-injury rabbit model. Comp Med 2009; 59: 567-72.

13. Nowsheen S, Yang ES. The Intersection Between Dna Damage Response And Cell Death Pathways. Exp Oncol 2012; 34: 24354.

14. Choi YH, Cowan DB, Moran AM, Colan SD, Stamm C, Takeuchi K, et al. Myocyte apoptosis occurs early during the development of pressure-overload hypertrophy in infant myocardium. J Thorac Cardiovasc Surg 2009; 137: 1356-62. [CrossRef]

15. Bepler G, Zheng Z, Gautam A, Sharma S, Cantor A, Sharma A, et al. Ribonucleotide reductase M1 gene promoter activity, polymorphisms, population frequencies, and clinical relevance. Lung Cancer 2005; 47: 183-92. [CrossRef]

16. Garavaglia GE, Messerli FH, Schmieder RE, Nunez BD, Oren S. Sex differences in cardiac adaptation to essential hypertension. Eur Heart J 1989; 10: 1110-4. [CrossRef]

17. Gradman AH, Alfayoumi F. From Left Ventricular Hypertrophy to Congestive Heart Failure: Management of Hypertensive Heart Disease. Prog Cardiovasc Dis 2006; 48: 326-34. [CrossRef] 